\title{
COMMUTATORS OF IMAGINARY POWERS OF LAPLACE OPERATORS
}

\author{
SungGEUM HONG
}

Abstract. We obtain continuity properties of commutators generated by the imaginary powers of the Laplace operator and BMO functions on Hardy spaces and certain Hardy type spaces.

Mathematics subject classification (2000): 35J05, 42B20, 42B30.

Key words and phrases: commutators, Laplace operators, Hardy type spaces, BMO $\left(\mathbb{R}^{n}\right)$.

\section{REFERENCES}

[1] J. ALVAREZ, Continuity properties for linear commutators of Calderón-Zygmund operators, Collect. Math. 49 (1998), 17-31.

[2] J. Alvarez, R. Bagby, D. S. KuRTZ AND C. PÉREZ, Weighted estimates for commutators of linear operators, Studia Math. 104 (1993), 195-207.

[3] M. CHRIST, Weak type $(1,1)$ bounds for rough operators, Ann. Math. 128 (1988), 19-42.

[4] R. COIFMAn, R. ROCHBERG AND G. WeIss, Factorization theorems for Hardy spaces, Ann. Math. 103 (1976), 611-635.

[5] M. Cowling AND G. Mauceri, On maximal functions, Rend. Sem. Mat. Fis. Milano, 49 (1979), $79-87$.

[6] M. COWLING AND A. SIKORA, A spectral multiplier theorem for a sublaplacian on SU(2), Math. Z. 238 (2001), 1-36.

[7] J. GarCía-Cuerva And J. L. Rubio DE Francia, Weighted norm inequalities and related topics, North-Holland Mathematicsl Studies, 116 (North-Holland, Amsterdam, 1985).

[8] H. GunAWAN, Some weighted estimates for imaginary powers of Laplace operators, Bull. Austral. Math. Soc. 65 (2002), 129-135.

[9] H. GUNAWAN AND J. WRIGHT, Weighted estimates for some singular integrals, preprint.

[10] Y. KOMORI, Commutators of singular integrals on $H_{b}^{p}\left(\mathbb{R}^{n}\right)$ at critical index, Far East J. Math. Sci, 3 (2001), 631-636.

[11] B. MuCKenhoupt, On certain singular integrals, Pacific J. Math. 10 (1960), 239-261.

[12] M. PALUSZYŃSKI, Characterization of Lipschitz Spaces via Commutator of Coifman, Rochberg and Weiss: A Multiplier Theorem for the Semigroup of Contractions, Thesis, Washington University, 1992.

[13] A. SiKora AND J. WRIGHT, Imaginary powers of Laplace operators, Proc. Amer. Math. 129 (2001), $1745-1754$.

[14] C. PÉREZ, Endpoint estimates for commutators of singular integral operators, J. Funct. Math. 128 (1995), 163-185.

[15] E. M. STEIN, Singular integrals and differentiability properties of functions, Princeton Mathematical Series, 30 (Princeton Univ. Press, 1970).

[16] E. M. STEIN, Harmonic analysis: Real variable method, orthogonality and oscillatory integrals, Princeton Mathematical Series, 43 (Princeton Univ. Press, 1993). 